AWEJ for Translation \& Literary Studies Volume, 1 Number 3, August 2017

DOI: http://dx.doi.org/10.24093/awejtls/vol1no3.10

Pp.139-161

\title{
The Use of Tautology in "The Thorn" by William Wordsworth: A Stylistic Study
}

\author{
Nawar Hussein Rdhaiwi Al-Marsumi \\ English Department, College of Languages, \\ Baghdad University, Baghdad, Iraq
}

\begin{abstract}
A tautology is to say the same thing twice where part of the sentence is redundant. The words are used and then expanded further in a way as if it has never been spoken before. It is the repetition or duplication of words; however; it has been argued that every repetition is not a tautology. Poets use this part of speech in their work for many years. Owing to its principal use in poems, it deserves an investigatory research work. This study aims at analyzing 'tautologies' in William Wordsworth's poem "The Thorn" from the viewpoint of stylistic analysis. This analysis can show the significance of the use of tautological words to conclude whether tautologies produce redundancy or make a poem beautiful. Leech (1969) is the model adopted in analyzing the selected poem where the concept of "Foregrounding" is introduced as being considered an important field of stylistic analysis. The analysis is quantitative where a statistical analysis is conducted. It is hypothesized that tautology is redundancy, whereas the findings reveal it as an expression of the depth of the human feelings. Wordsworth has successfully used tautology to achieve the themes included in his poem. This paper is hoped to help researchers know the position and effectiveness of tautology in literary texts, specifically, in poems.
\end{abstract}

Keywords: Duplication, foregrounding, redundancy, repetition, stylistic analysis, tautology

Cite as: Al-Marsumi, N.H. R. (2017). The Use of Tautology in "The Thorn" by William Wordsworth: A Stylistic Study. Arab World English Journal for Translation \& Literary Studies, 1(3).

DOI: http://dx.doi.org/10.24093/awejtls/vol1no3.10 